
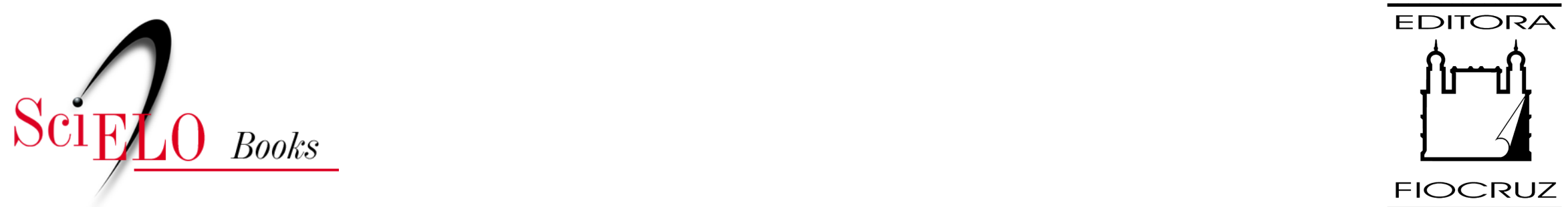

\title{
Da Preexistência a 1900
}

\author{
Renato da Gama-Rosa Costa \\ Alexandre Jose de Souza Pessoas \\ Benedito Tadeu de Oliveira (coord.)
}

COSTA, R. G. R., and PESSOA, A. J. S. Da Preexistência a 1900. In.: Um lugar para a ciência: a formação do campus de Manguinhos [online]. Coord inator Benedito Tadeu de Oliveira. Rio de Janeiro: Editora FIOCRUZ, 2003, pp. 20-37. História e saúde collection. ISBN: 978-65-5708-113-6. https://doi.org/10.7476/9786557081136.0004.

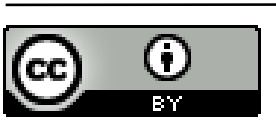

All the contents of this work, except where otherwise noted, is licensed under a Creative Commons Attribution 4.0 International license.

Todo o conteúdo deste trabalho, exceto quando houver ressalva, é publicado sob a licença Creative Commons Atribição 4.0.

Todo el contenido de esta obra, excepto donde se indique lo contrario, está bajo licencia de la licencia Creative Commons Reconocimento 4.0. 


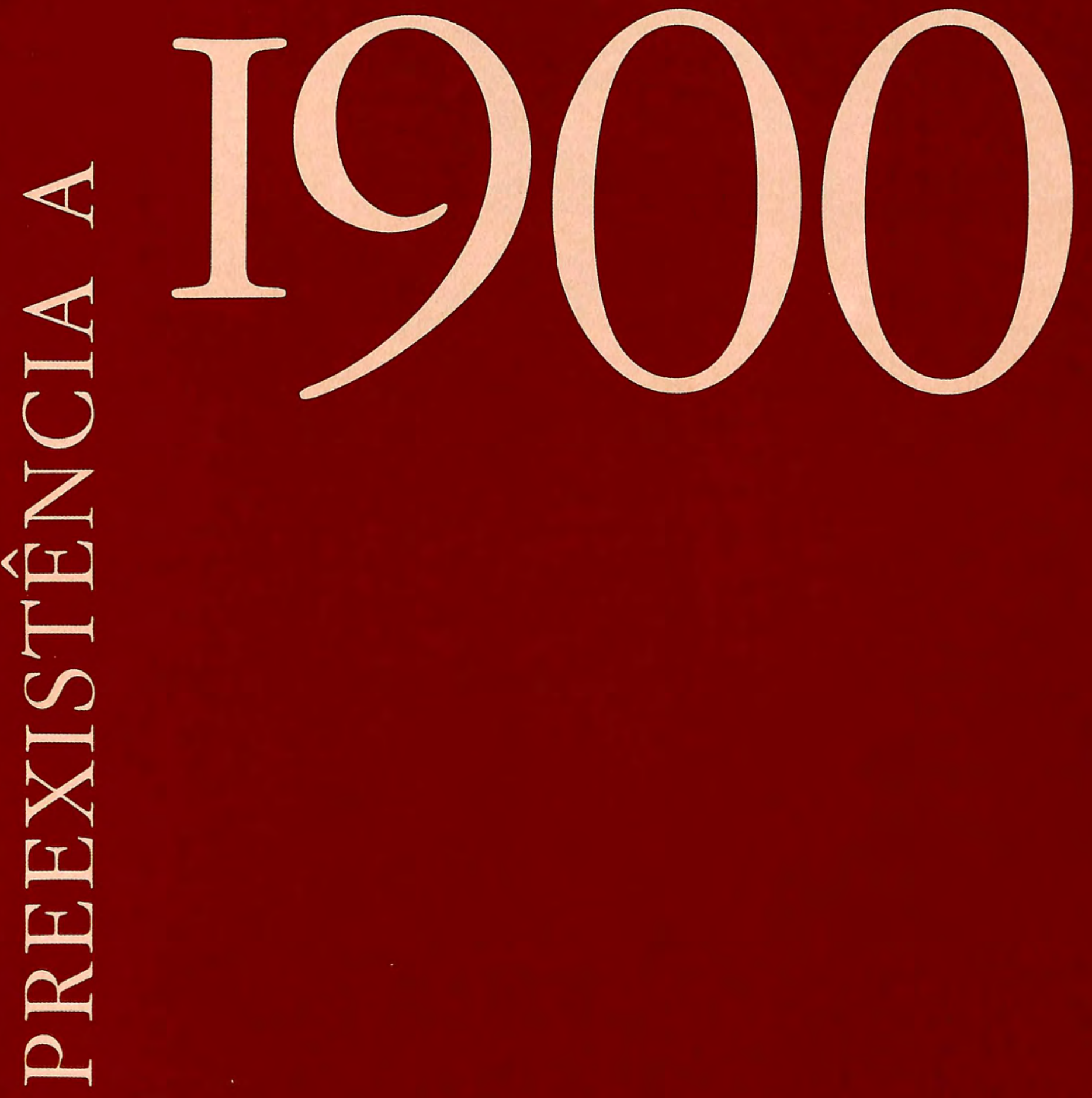

$\overleftrightarrow{\Omega}$ 


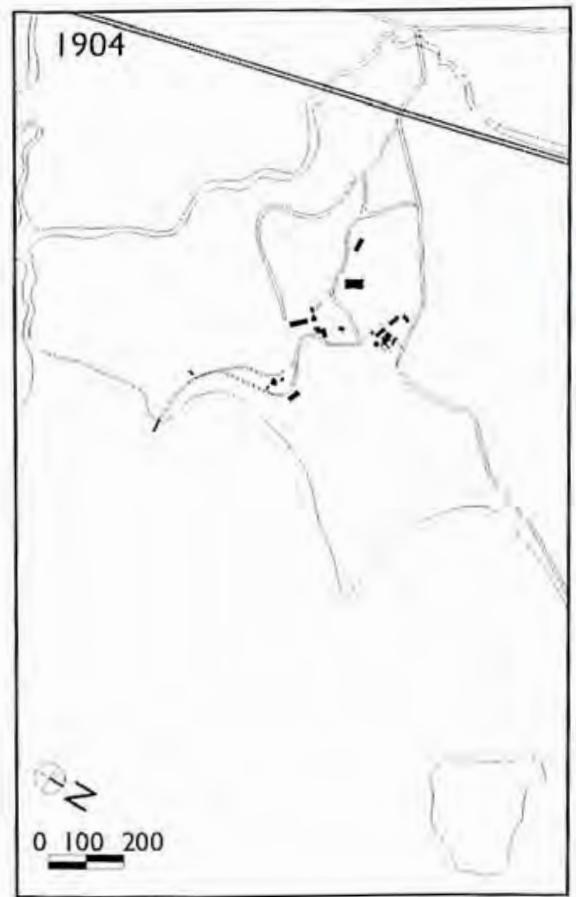

1910

Até 1904
01 Chaminé
02 Forno de incineraçāo de lixo
03 Depósito do incinerador
04 Barracáo para animais
05 Depósito
06 Depósito
07 Gaiola para macacos

08 Gaiola para cobras e cobaias
09 Pequeno laboratório
Instituto Soroterápico
10 Sede do Instituto Soroterápico
11 Cocheira Instituto Soroterápico
12 Antiga Cavalariça
13 Barracão para operários
14 Cocheira

08 Gaiola para cobras e cobaias

veno laboratorio

Sede do Instituto Soroterápico

12 Antiga Cavalariço

14 Cocheira
15 Residêncio para funcionários

16 Depósito

17 Pesqueira

18 Cais

19 Biotério 
$V_{16}$
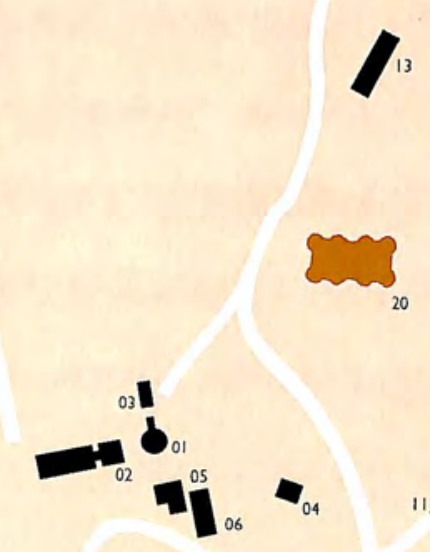

$\lim _{20}$

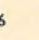

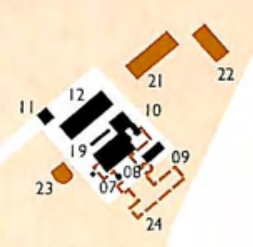

I. 
( atual campus da Fundação Oswaldo Cruz, localizado no bairro de Manguinhos, ${ }^{5}$ no município do Rio de Janeiro, possui aproximadamente $850.000 \mathrm{~m}^{2}$ e tem seus limites definidos pelas avenidas Brasil e Leopoldo Bulhões, pela Rua Sizenando Nabuco e pelo Rio Faria Timbó, com uma extensão correspondente às instalações da antiga Delegacia da Saúde, situada no lado par da Avenida Brasil.

A área onde se localiza Manguinhos era habitada, no início do século XVI, pelos índios tupinambás que deram o primeiro nome à terra: Anhumas ou Inhuma, corruptelas de nhãum, que era a ave preta com um chifre pontiagudo sobre a cabeça, muito comum naquela região pantanosa. ${ }^{6}$ Em 1565, ano da fundação da cidade do Rio de Janeiro, Estácio de Sá (o fundador) concedeu duas sesmarias na atual região de Manguinhos: a dos Jesuítas que deu origem à Fazenda do Engenho Novo, e a de propriedade de Antônio da Costa, que criou o futuro Engenho da Pedra. O Engenho da Pedra abrangia os atuais bairros de Manguinhos, Olaria, Bonsucesso e Ramos.? A partir daí até o século XVIII,

\footnotetext{
${ }^{5} \mathrm{O}$ Jornal do Commercio de 26 de fevereiro de 1915 noticiava: "Dizem chamar-se Manguinhos por ter sido um lugar favorecido, isto é, de poucos mangues, naquela vasta área pantanosa que era toda a margem da Leopoldina, até então ocupada por um ou outro sitiante, que aproveitavam os trechos de chão firme para plantar frutas como melancia, figo e fruta-do-conde" (Acervo DPH/COC, Fiocruz).

${ }^{6}$ Em Almanaque Suburbano (1941:50-51): da toponímia, Theodoro Sampaio diz: "Inhaúma, corruptela de 'nhamum', ave preta (Palmidia Cornuta)". Vieira Fazenda, em crônica magistral com exaustiva documentação, esclarece que essas aves preferiam lugares pantanosos.

Benchimol (1990)
}

Primitivas instalaçóes da Fazenda de Manguinhos, Pedro Aftonsopara o Instituto Soroterápico Federal. DAD/Fiocruz) 
No último quartel do século XIX, a freguesia de Inhaúma era percorrida por várias ferrovias: pela Estrada de Ferro D. Pedro II, atual Central do Brasil, inaugurada em 1858, ${ }^{11}$ pela Estrada de Ferro Melhoramentos do Brasil, inaugurada em 1893 e mais tarde incorporada à Central como linha auxiliar, pela Rio D’Ouro, concebida em 1876, mas que começou a funcionar apenas em $1883^{12}$ e ainda pela Cia. Leopoldina Railway, vetor de crescimento e expansão do subúrbio da capital fecteral e que construiu na região as estaçôes de Penha, Bonsucesso e Ramos em 1886. A expansão em direçào à regiào norte prosseguiu com as estações de Lucas, daí o nome que persiste, 'Parada de Lucas' em 1908 e Vigário Geral em 1910. ${ }^{13}$ A parada do Amorim também só foi oficializada como estação em 1910, muito provavelmente devido ao fluxo de pessoas que seguiam para as obras e os laboratórios do campus de Manguinhos e que solicitavam uma parada nessa região. $\mathrm{O}$ tempo médio de viagem entre a estação de partida, Leopoldina, e a estação do Amorim era de 11 minutos.

Importante para a regiào era a estrada que dava acesso ao porto de Inhaúma, por onde escoavam os produtos agrícolas produzidos nas freguesias rurais de Inhaúma e Irajá e que abasteciam o mercado da cidade do Rio de Janeiro. ${ }^{1+}$

Em 1885, Luiz Joaquim Estrada Meyer e Frederico Duque Estrada Meyer venderam uma propriedade em Inhaúma, já designada como Fazenda de Manguinhos, a Dona

\footnotetext{
1 Primeira ferrovia do Pais e elo de ligação do Município Neutro da Corte com as provincias de Minas Gerais e São Paulo

${ }_{12}$ Como vetor de transporte material para as obras de construçâo da nova rede de abastecimento de água da cidade do Rio de Janeiro, captada em mananciais da Serra do Mar, em Tinguá e Xerém, e posteriormente utilizada como transporte de passageiros.

Santos (1996).

No AGCRJ, códice 32-2-1, p.105, 106 e 109. encontram-se notícias da construção, entre os anos de 1880 e 1885 , da estrada do porto de Inhaúma.
} 
Alexandrina Rosa de Carvalho. Em 1892, a fazenda, já em completo estado de abandono, foi desapropriada pelo governo de Floriano Peixoto.

Em consolidação das leis e posturas municipais, Alexandrino Freire do Amaral relata a aquisição do terreno pela Prefeitura, local onde se estabeleceu a Fundação Oswaldo Cruz:

O terreno Municipal em que se acha situado o laboratório para o preparo do soro contra a peste bubônica foi desapropriado pela Prefeitura a D. Alexandrina Rosa de Carvalho, ex ví do clecreto federal n. 1.141 B de 18/11/1892.

A Municipalidade foi mandada immittir na posse do terreno, por sentença do juiz dos feitos da Fazenda Municipal de 8 de março de 1893, mandada cumprir em 22 de agosto do mesmo anno; tendo sida indemnizada a ex-proprietária do preço da avaliação arbitrada, em oitenta contos de réis, em 19 do referido mez de agosto.

O terreno que constituía a denominada Fazenda de Manguinhos possue a área de 853.363,00 metros quadrados e uma extensão de 1.564 m, 96 pela estrada para o Porto de Inhaúma; medindo pelo lado do mar $1.339 \mathrm{~m}$, e pelos Manguinhos, $1.115 \mathrm{~m}$. É o que consta dos autos da desapropriação.

Pelos mesmos autos verifica-se que D. Alexandrina de Carvalho houve esse terreno por compra a Luiz Joaquim Estrada Meyer, conforme escriptura de 20 de novembro de 1855, em notas do tabelião Manuel Hilario Pires Ferrão, e a Frederico Duque Estrada Meyer, conforme escriptura de 27 de novembro de 1855, em notas do mesmo notário.

A Prefeitura adquiriu este terreno para nelle serem construíclos fornos de incineração do lixo da cidade, pelo systema dos engenheiros Gierth e Lavagnino, preferido em concurrencia pública pela Inspetoria Geral de Hygiene em 1887, e cujo privilégio no Rio de Janeiro foi adquirido pela administração municipal, conforme contracto de 19 de setembro de 1892 , e pelo qual a firma constituída pelos engenheiros C. Arno Gierth e G. F. Lavagnino comprometteu-se também a executar uma bateria de fornos, conforme os planos approvados e sob a fiscalizaçào da Directoria Geral de Obras e Viaçào.

Terminado o praso de dous annos, estipulado no termo cittado de 15 de maio de 1894 para a conclusão das obras, não estavam estas terminadas. Concederam-se aos contractantes sucessivas prorrogaçōes até 31 de dezembro de 1896, e finalmente ficaram suspensos os trabalhos, por despacho do Prefeito, em 21 de fevereiro de 1899.15 
O prefeito Cesário Alvim, em 22 de agosto de 1899, encarregou o Barão de Pedro Affonso, à frente do Instituto Vacínico Municipal desde 1894, de obter soros contra a peste bubônica. Diante da demora nos pedidos para a França e a Alemanha, o Barão resolveu criar um Instituto Soroterápico dentro da cidade do Rio de Janeiro, anexado ao seu Instituto Vacínico. Autorizada a despesa em 19 de outubro do mesmo ano, após o surgimento da peste em Santos, ele mesmo começou a procurar o local para a instalação do novo instituto.

Depois de percorrer as ilhas da Baía de Guanabara e a Quinta da Boavista, o Barão de Pedro Affonso escolheu Manguinhos, pelo seu isolamento dos centros populosos e por sua fácil comunicação por mar e por terra. Em vista da urgência o próprio Barão fez as primeiras modificações.

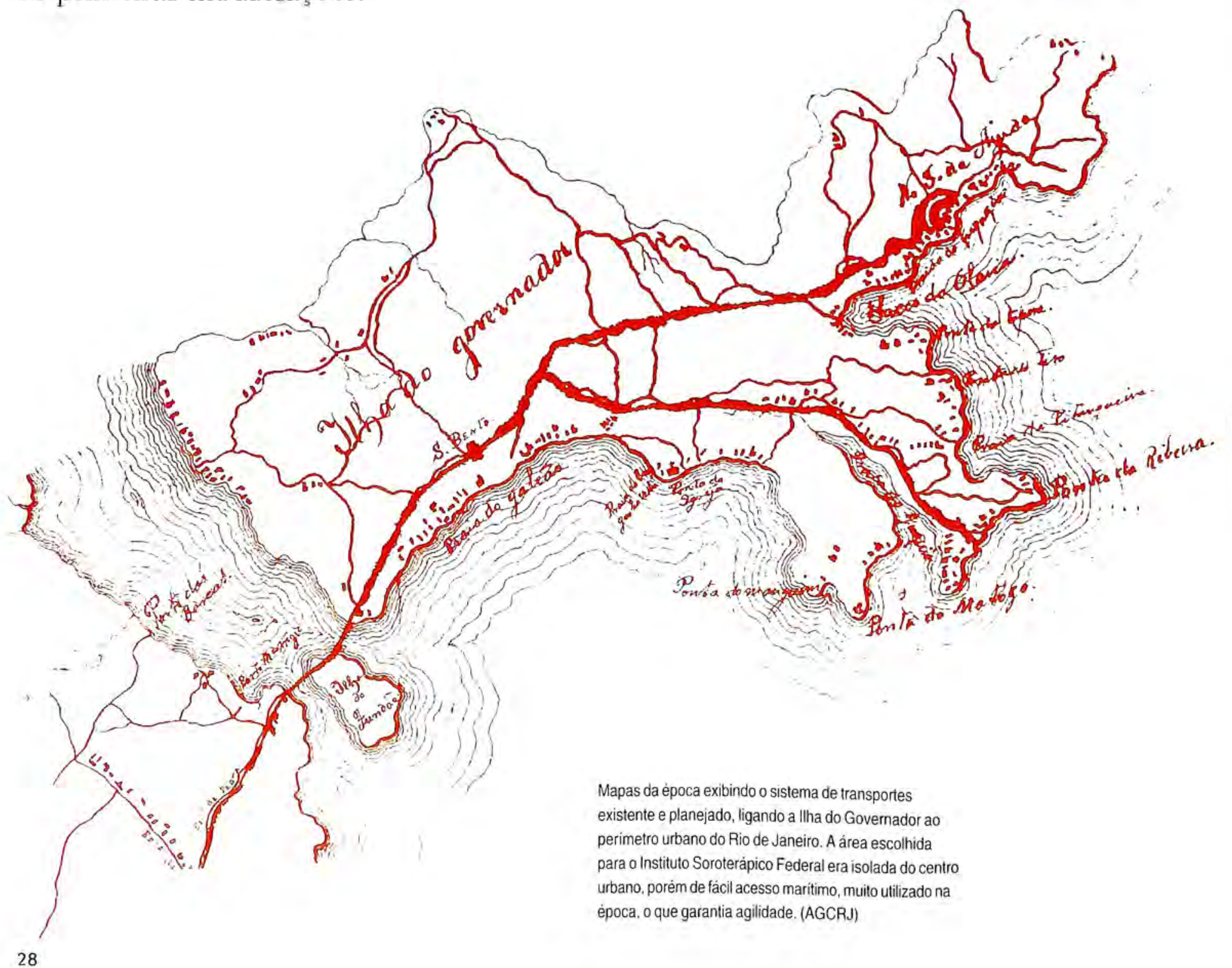




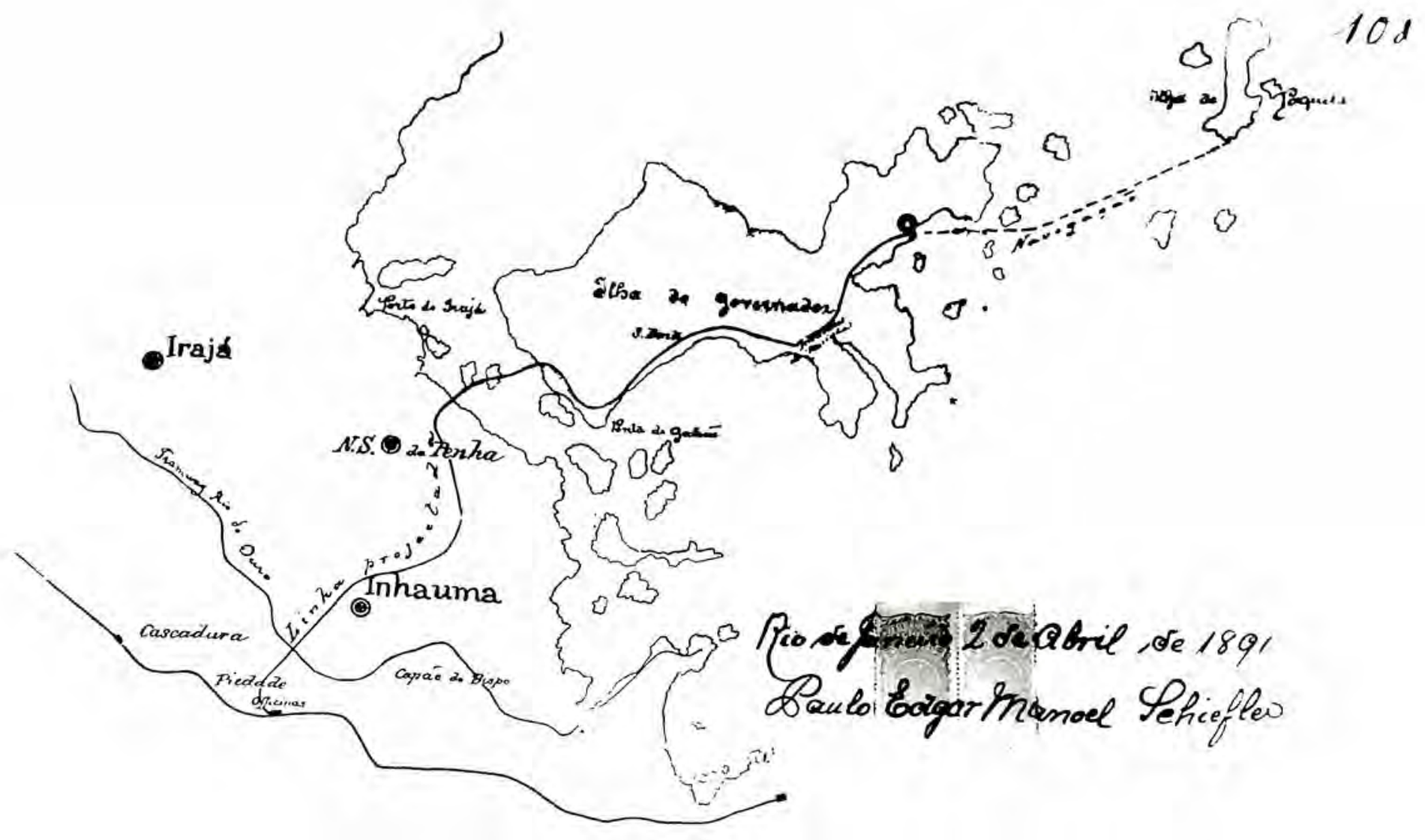

ao atual campus da Fiocruz a seguinte infra-estrutura:

Na data da acquisição do terreno havia dous prédios, que foram reconstruídos pela Prefeitura, um para escriptório e almoxarifado, e o outro para residência do pessoal superior. Posteriormente realisaram-se as seguintes construçòes:

Barracào para morada do pessoal operário.

\footnotetext{
${ }^{16}$ O Barāo de Pedro Affonso escreveu para o Jornal do Commercio, em 26 de fevereiro de 1915, respondendo a uma notícia vinculada em 20 de fevereiro daquele ano, intitulada 'Manguinhos'. Segundo Pedro Affonso, a noticia continha algumas "inexatidōes" que diziam respeito ao papel que ele representou na criaçāo e direção do Instituto de Manguinhos.
} 
Dous barracões para carruagens.

Dous ditos para depósito de ferramentas.

Galpão para officina de carpintaria e cozinha do pessoal operário.

Barracão para lazareto de isolamento. Esta e as cinco construções precedentes cobrem uma área de $461 \mathrm{~m}^{2}$.

Galpão para estrebaria, com $57 \mathrm{~m}^{2}$ de área,

Galpào para a ferraria, com a área de $99 \mathrm{~m}^{2}$.

Casa de machinas, com $171 \mathrm{~m}^{2}$ de área.

Ponte de atracação, de madeira, com mólhe de pedra e guyndaste giratório, tendo a estensào total de $110 \mathrm{~m}$.

Officina annexa à casa de machinas, com a área de $107,25 \mathrm{~m}^{2}{ }^{217}$

Para iniciar os trabalhos, o Barão de Pedro Affonso convidou Ismael da Rocha, Oswaldo Cruz e H. Vasconcellos, dois alunos de medicina e um veterinário da Europa, autorizado pelo Governo. Em 10 de dezembro de 1899 o Barão partiu para a Europa, deixando em construção as obras dos laboratórios, fiscalizadas pela prefeitura, a fim de conseguir o material necessário. Voltou em 28 de fevereiro de 1900 com todo o material de que precisaria e trouxe contratado o veterinário bacteriologista francês Carrière, recomendado por Émile Roux, professor do Instituto Pasteur em Paris. Mas o prefeito era agora Coelho Rodrigues, que havia cortado qualquer verba para o Instituto. Nuno de Andrade, então Diretor da Saúde Pública, auxiliou o Barão a encaminhar um pedido ao Ministro do Interior, Epitácio Pessoa, carta que obteve resposta no ofício n 490 de 25 de maio de 1900 , autorizando a conclusão da instalação do Instituto. O Barão reiterou os convites de trabalho aos cientistas, mas tanto Carrière quanto Ismael da Rocha rescindiram o contrato. Oswaldo Cruz se ofereceu para ser o encarregado de todo o trabalho para o qual faltavam esses cientistas.

No ano de 1899 apareceram notícias sobre a retomada das construções e reformas dos edifícios da antiga Fazenda de Manguinhos. 


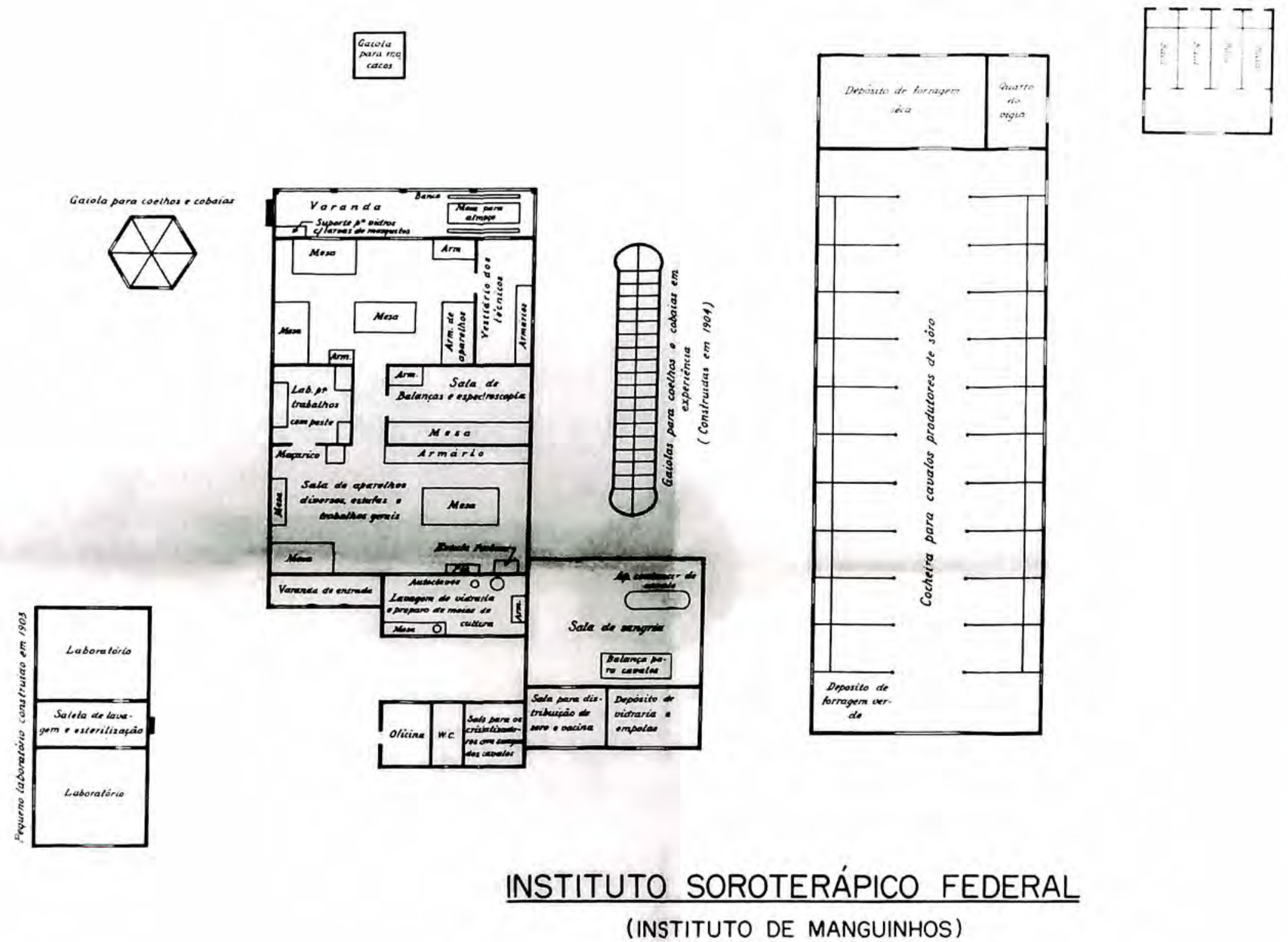

PLANTA E LOCALIZACCAOO APROXIMADAS DO PRIMITIVO LABORATÓRIO E DAS INSTALAÇŌES ANEXAS

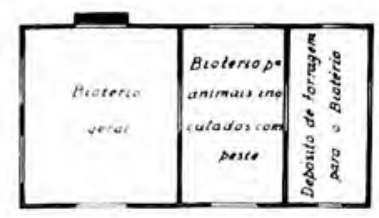

$1900-1903$

Implantaçăo original do Instituto Soroterápico do Barão de Pedro Affonso. A construção longilinea, um biotério para pequenos animais, que aparece ao centro, foi a primeira intervenção de Luiz Moraes Jt. e serviu como balizador para as obras do futuro núcleo do Instituto. A construção à direita, uma estrebaria, resistiu até meados da década de 30. (DAD/Fiocruz) 
Auctorisado pelo artigo 37 da lei orçamentária de 4 de janeiro de 1899, o Prefeito Dr. Cesario Alvim abriu um crédito extraordinário e especial de 90 contos de réis a fim de subvencionar o illustre brasileiro dr. Pedro Affonso Franco na creação e custeio, nesta capital, de um laboratório para o fabrico de sôro anti-pestoso, ficando annexo ao Instituto Vaccinico Municipal.

(...) Em 21 de outubro de 1899 foi acceita a proposta da Companhia Edificadora para a execução das obras de adaptação, e com a mesma empreza lavrou-se o respectivo contracto pela quantia de 52.000\$; devendo o forno para a incineração dos animais utilizados ser construído administrativamente pela Directoria de Obras. ${ }^{18}$

Nesse período, a Cia. Edificadora Nacional contratada pela prefeitura do Distrito Federal foi autorizada a usar nas obras de adaptações das construções do Instituto Soroterápico o granito da região, posteriormente utilizado por Oswaldo Cruz na construção do Conjunto Arquitetônico de Manguinhos. ${ }^{19}$

O Decreto oficial de 25 de maio de 1900 marca o nascimento da instituição. ${ }^{20} \mathrm{O}$ decreto não apenas autorizava, por parte do Governo Federal, a conclusão das obras iniciadas por Pedro Affonso em Manguinhos no ano anterior, como também transferia suas instalações, até então pertencentes ao Instituto Vacínico, de alçada municipal, para a responsabilidade da Federação, com o nome de Instituto Soroterápico Federal. Até 9 de dezembro de 1902, Pedro Affonso acumulou a direção dos dois institutos, até que Oswaldo Cruz assumiu a direção do Soroterápico.

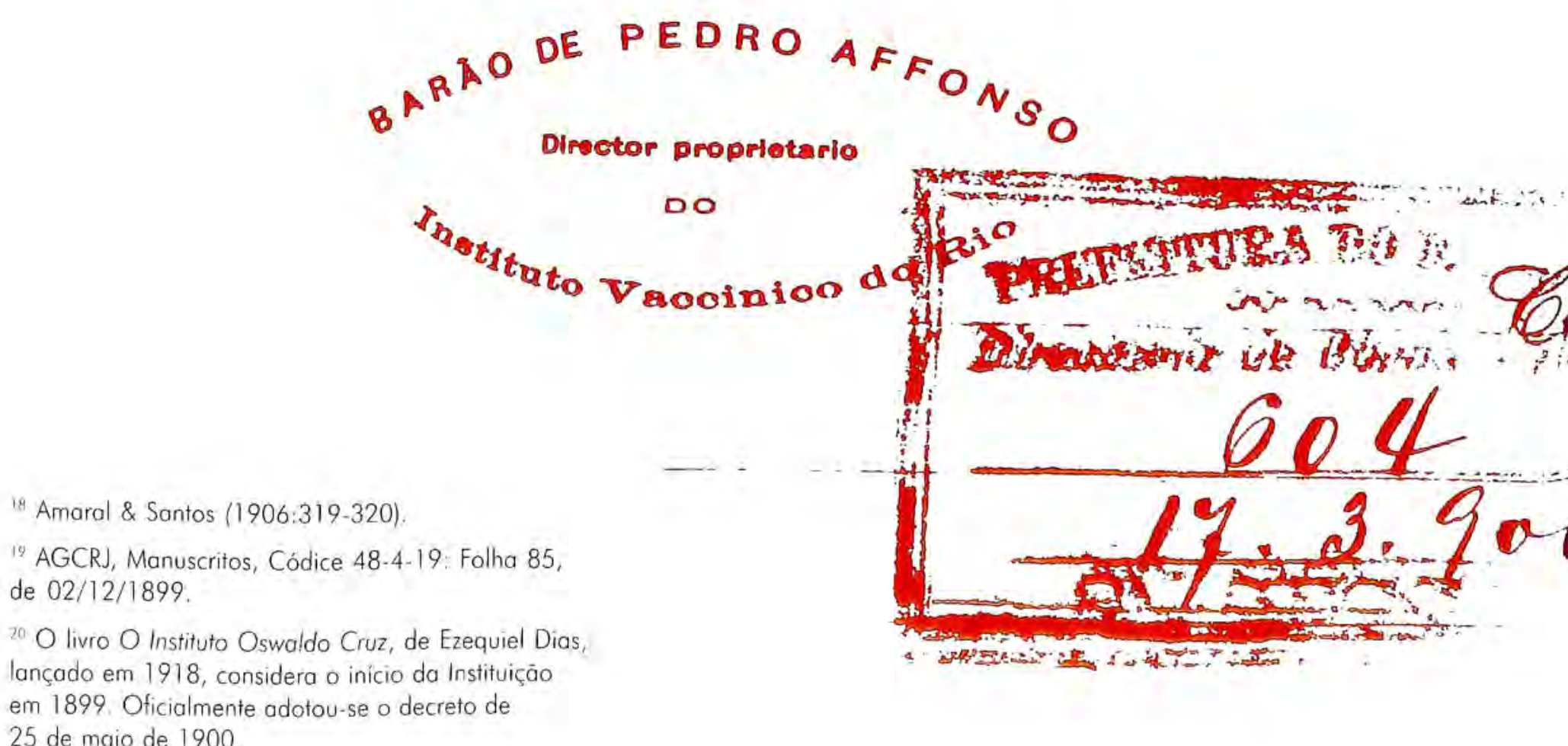




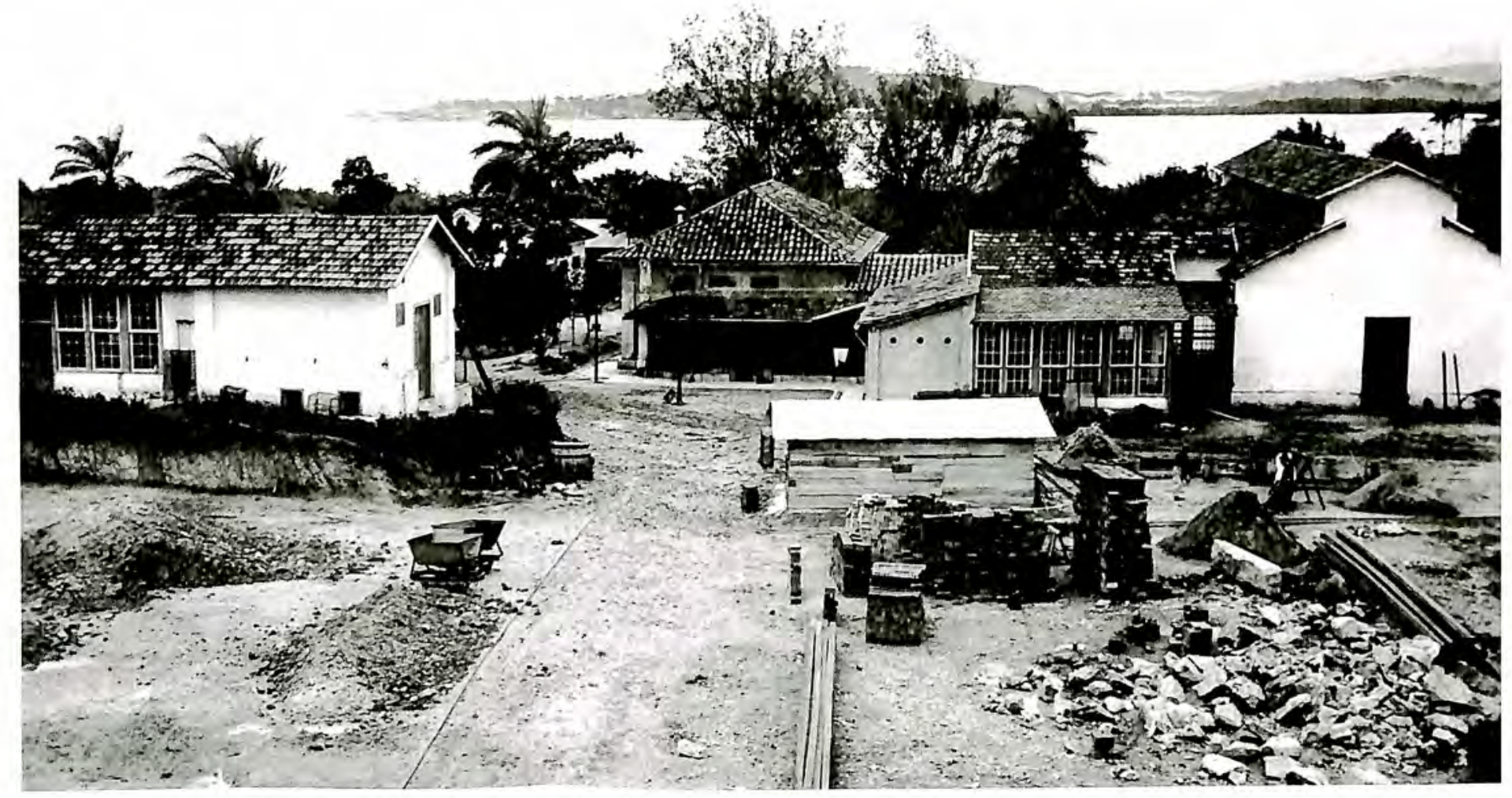

Inicio da construção da Cavalariça. A estrebaria, à direita, ocupou o lugar de uma edificação que comporia a futura Praça Pasteur, mas que não foi realizada. À esquerda o Instituto Soroterápico, funcionando ainda sos a administração de Pedro Affonso. (DAD/Fiocruz)

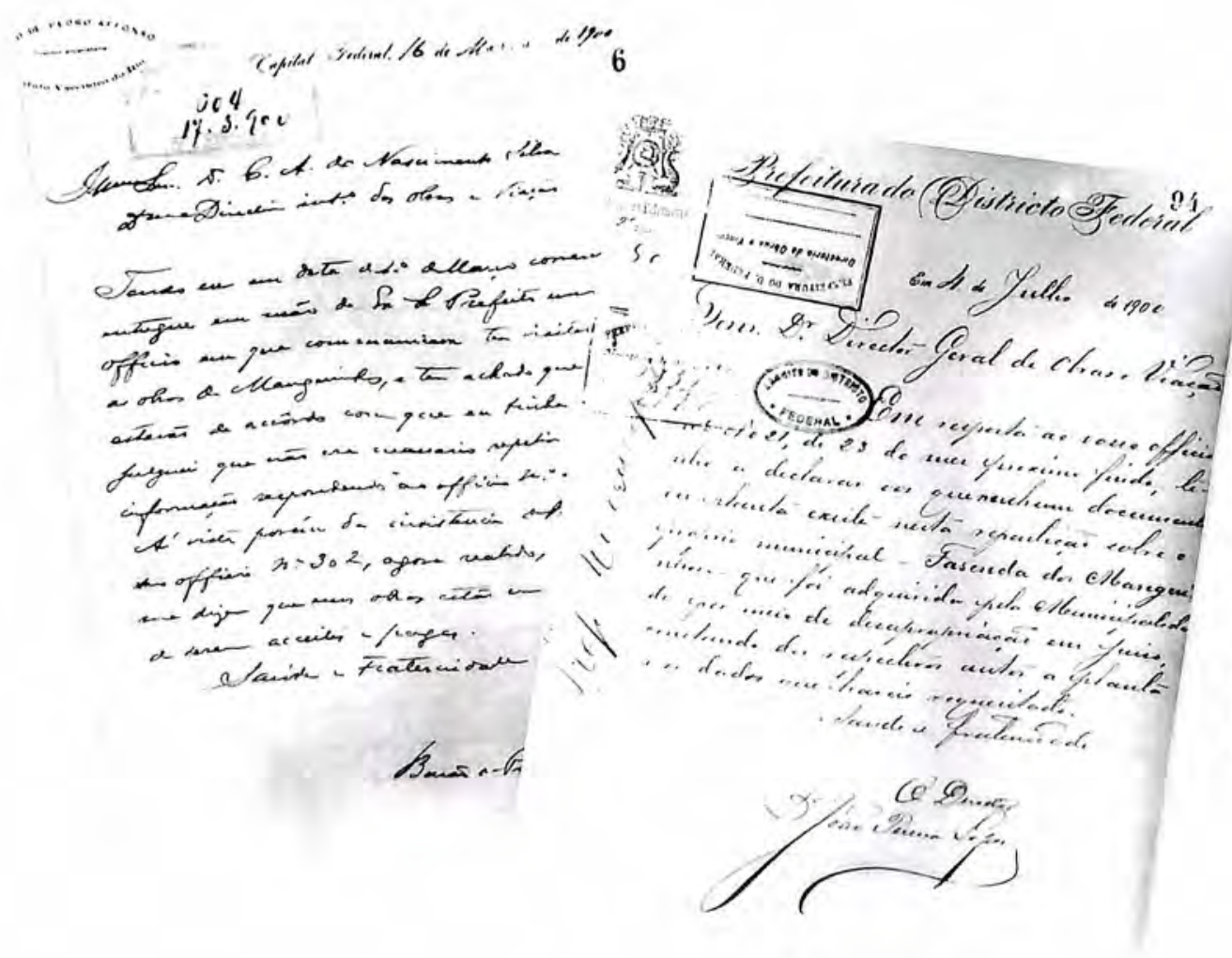


Os laboratórios de Manguinhos, inaugurados oficialmente em 23 de julho de 1900, foram instalados sobre duas colinas, distantes uma da outra cerca de $500 \mathrm{~m}$. Na colina mais alta localizava-se o laboratório para a fabricação do soro antipestoso, ao passo que na outra, o laboratório para a cultura é o preparo. O laboratório principal era composto de uma casa central e outras construçōes interligadas.

Sobre a casa central, temos a descrição de Henrique Aragão:

Uma casa térrea quase nada elevada do solo na qual, à entrada, voltada para o lado da estação da Leopoldina, havia uma estreita varanda à esquerda da qual se via um grande autoclave a carvão, para as esterilizações volumosas, e à direita um alambique para destilação de água. Dessa varanda passava-se à sala de trabalhos gerais, relativamente ampla, da largura do prédio. ${ }^{2 !}$

O acesso terrestre ao Instituto se dava através da estrada de Manguinhos, que fazia a ligação até a estação do Amorim da Estrada de Ferro Leopoldina Railway.

Apesar de isolado, o acesso ao centro da cidade era facilitado pelo transporte marítimo, como revelam documentos da época. Ezequiel Dias, entretanto, afirmava:

Com a via marítima quasi nào se podia contar, porque o estabelecimento não tinha lancha a vapor, servindo-se apenas (...) de uma das embarcaçôes pertencentes à repartiçăo da peșca (...). Era, no entanto, um meio pitoresco de transporte (...). O caminho habitual era o terrestre. Diariamente, tomava-se o trem das 10:30h na praça da República, o qual em 20 minutos ia até 'Sào Francisco Xavier', (...) cujo comboio suburbano ia em 10 minutos à parada do 'Amorim'. Ahi esperavam os médicos um servente com 2 cavallos de sella; para estudantes nâo havia conduç̃̃o. ${ }^{22}$

No fim do século XIX, o terreno da antiga fazenda de Manguinhos, onde estava sendo criado o Instituto Soroterápico Federal, possuía uma área equivalente ao atual campus da Fiocruz, 85 hectares. Ele era cortado pela Leopoldina Railway e tinha como limites o mar, o rio Faria e a estrada do Porto de Inhaúma. 


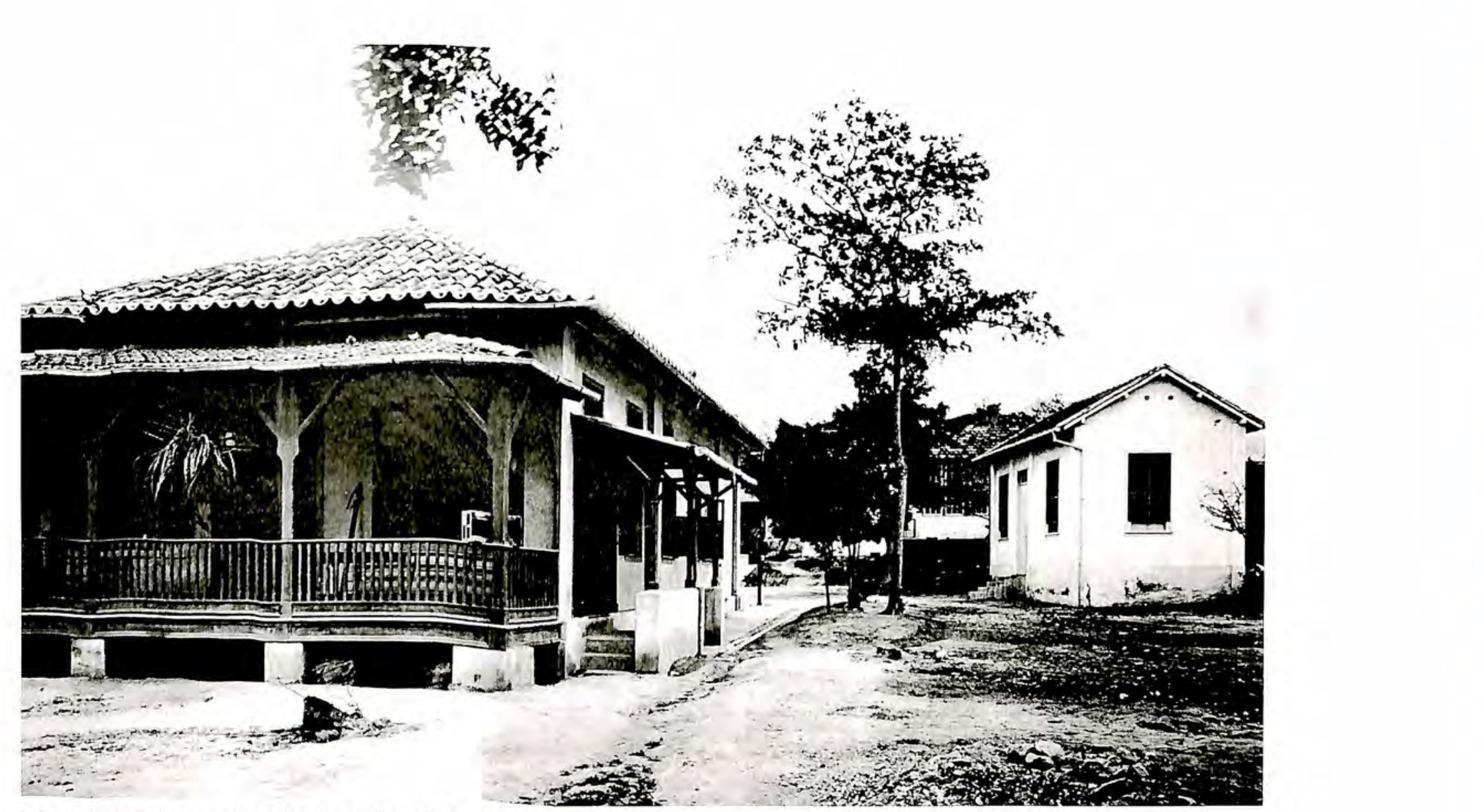

$\frac{\mathrm{C}^{4} \mathrm{c}}{\mathrm{g}}$

of

in

5.

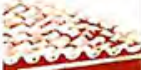
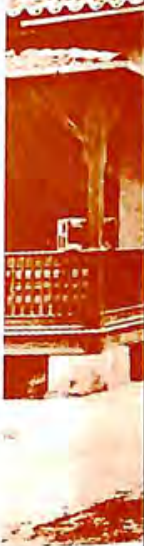

Laboratório principal com varanda, onde os funcionários e cientistas faziam suas refeiçōes. (DAD/Fiocruz)

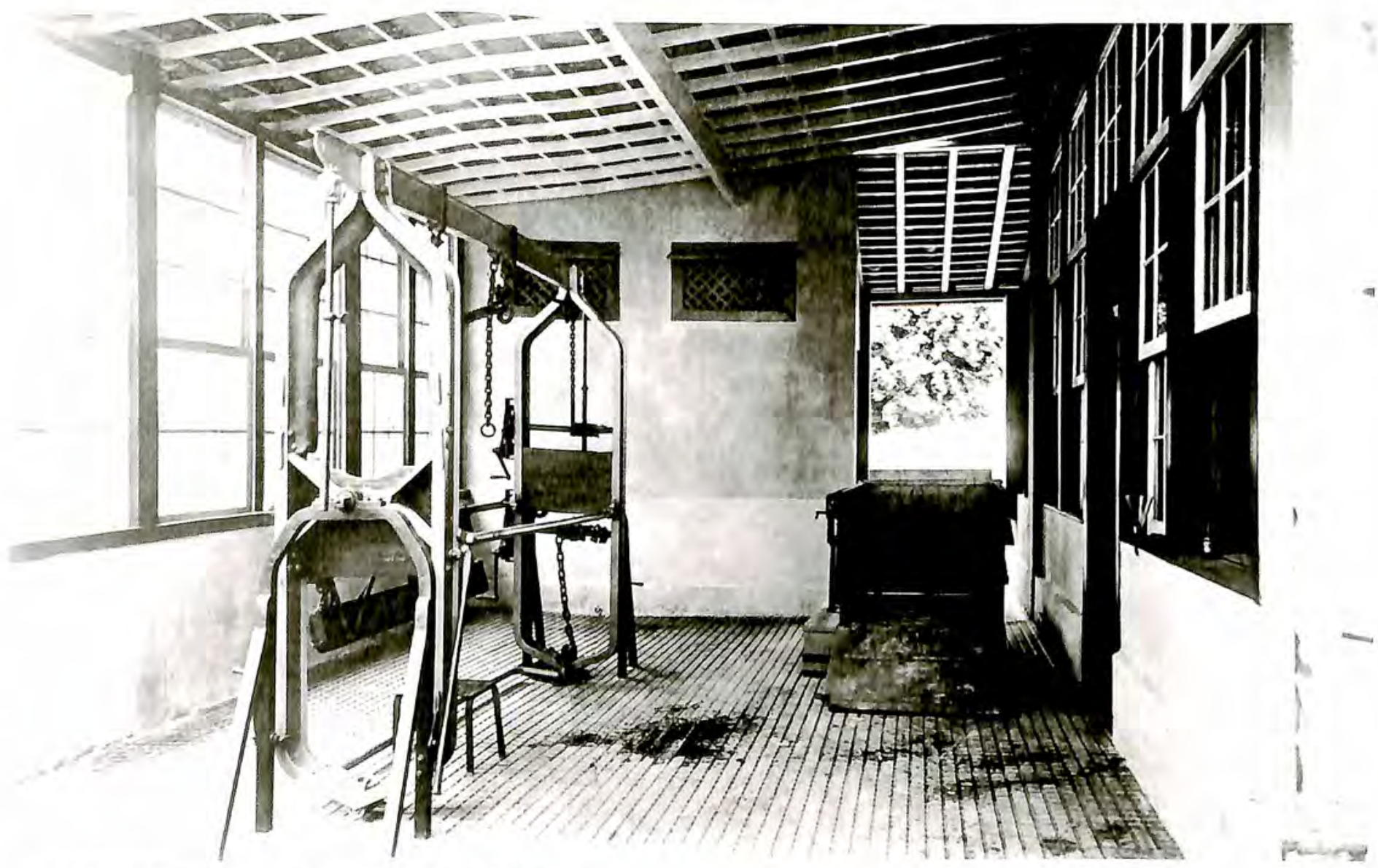

Interior do laboratơrio principal do Instituto Soroterápico Federal. (DAD/Fiocruz) 


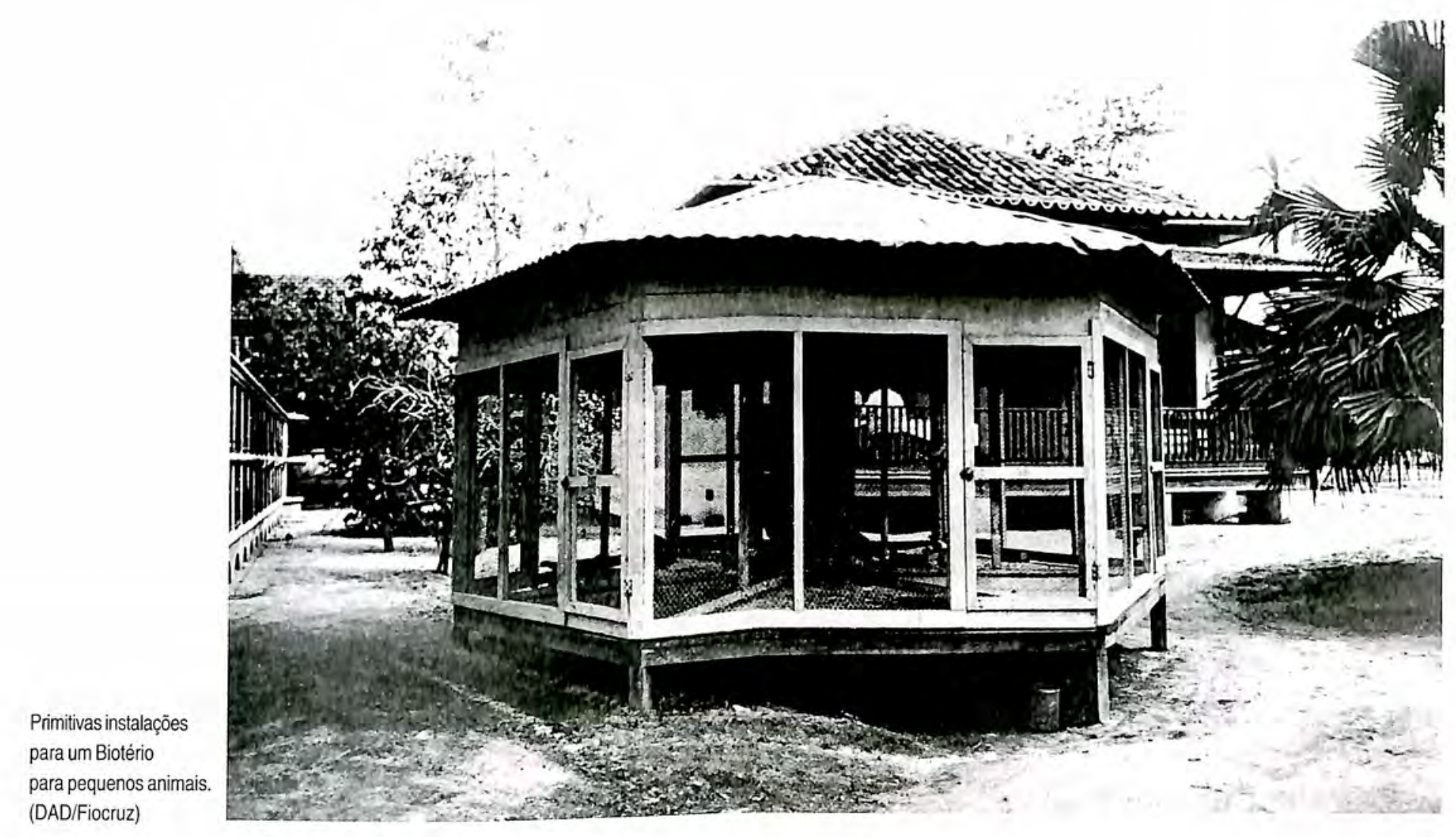

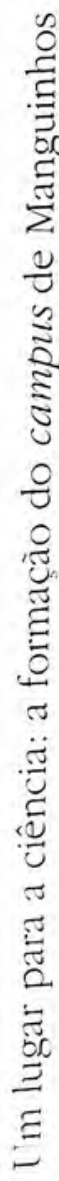

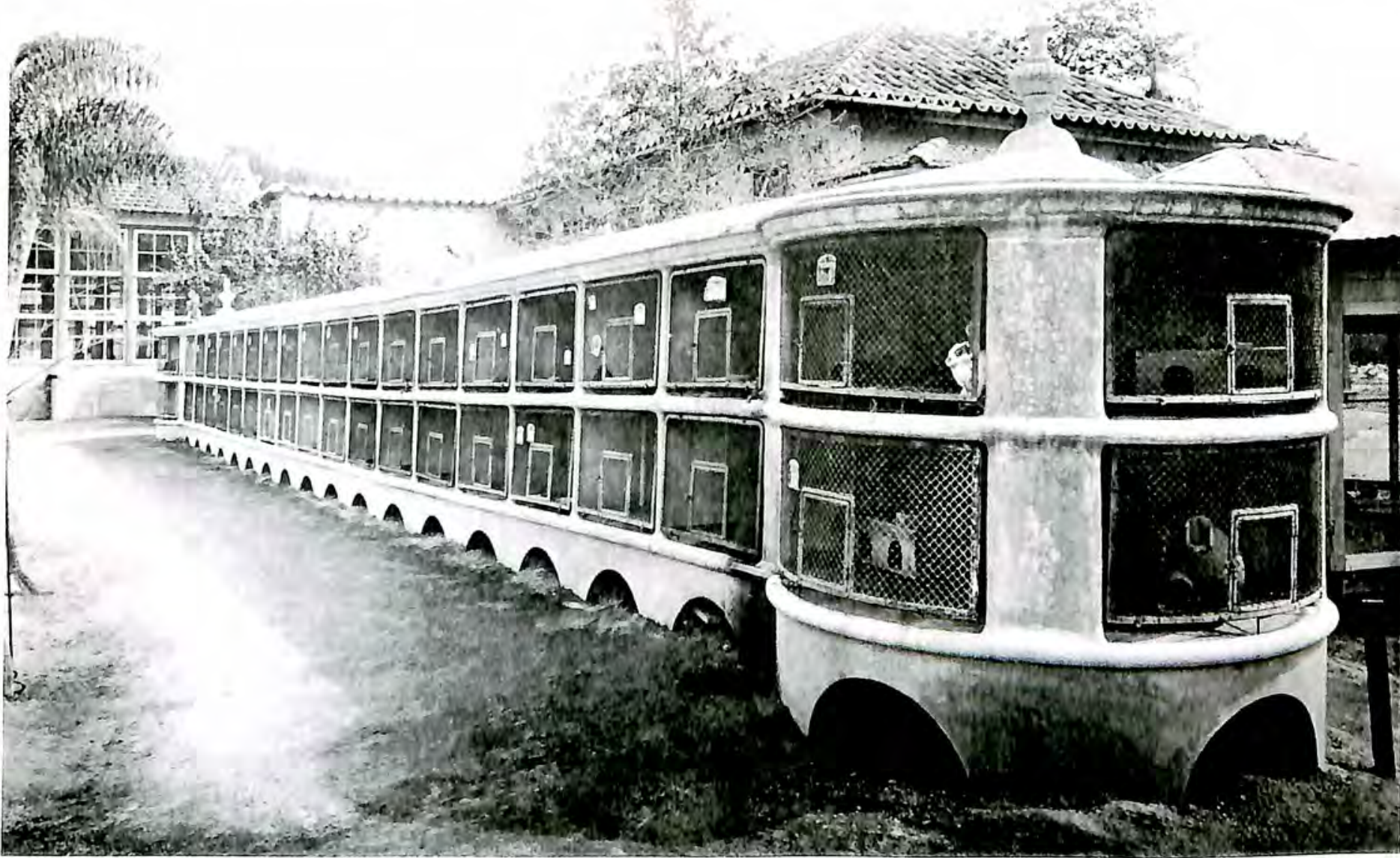

Biotério para pequenos animais, primeira intervençāo do engenheiro-arquiteto Luiz Moraes Jr. no Instituto. Embora tenha servido como balizador das futuras obras, teve vida curta. (DAD/Fiocruz) 


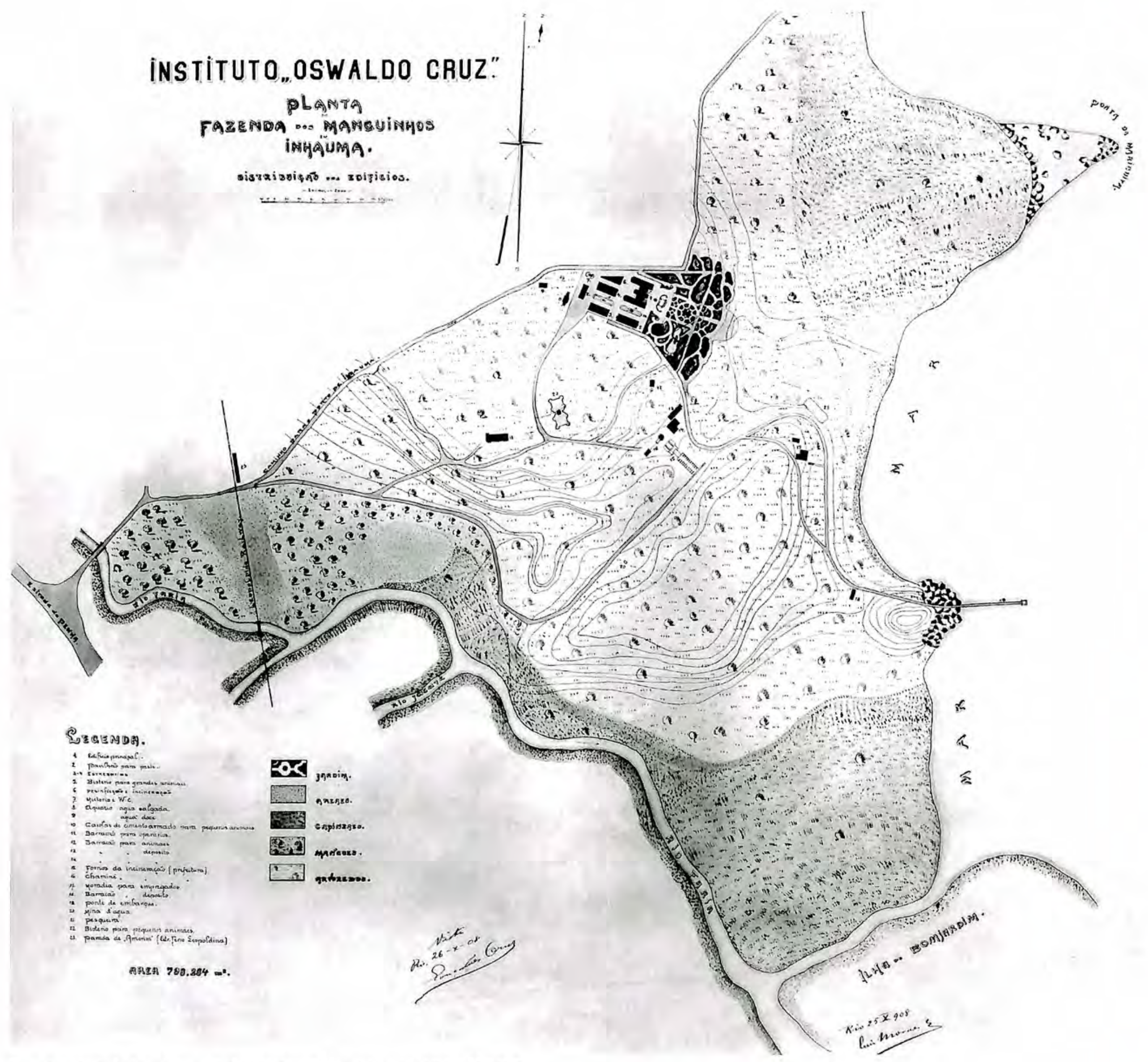

Planta de implantaçăo do conjunto arquitetônico histórico de Manguinhos original de Luiz Moraes Jr.

As novas instalaçōes de Oswaldo Cruz seriam superpostas às adaptadas pelo Barão de Pedro Affonso. (DAD/Fiocruz) 